\title{
CULTURABLE BACTERIA ASSOCIATED WITH THE CAVES OF MEGHALAYA IN INDIA CONTRIBUTE TO SPELEOGENESIS
}

\author{
Subhro BanerJee and SantaRam Joshi*
}

\begin{abstract}
The caves of Meghalaya in India are some of the longest caves in the subcontinent that have so far received negligible attention of geomicrobiologists. The present work was undertaken to discover and explore bacterial biofilms of various textures and colors from five caves of Meghalaya in North-East India. There are no previous specific scientific investigations from three of the studied caves. Thirty-two different culturable bacterial species belonging to sixteen different genera were characterized. Based on molecular identification, the isolates were related to nearest taxa, with the majority belonging to Bacillus and Pseudomonas. The study also indicated the capabilities of the isolated microbial strains to precipitate calcite, providing evidence for biotic processes involved in the formation of natural speleothems. SEM studies revealed an array of crystal polymorphs generated in vitro by the isolated bacteria similar to the microscopic observations of speleothems. The EDX spectrum showed that the precipitated crystals were predominately composed of calcium carbonate. The results endorse the hypothesis that the isolated chemoheterotrophic bacterial species contribute to the process of cave-speleothem formation in a hypogean environment.
\end{abstract}

\section{INTRODUCTION}

Microorganisms are active and passive promoters of redox reactions, influencing geological processes in caves that contribute to cave ecology (Northup and Lavoie, 2001). Caves with dim natural light and artificially lighted hypogean environments have been found to host diverse microorganisms that group themselves into biofilms associated with rock surfaces. These biofilms are complex aggregates of microorganisms embedded in a self-produced matrix (Banerjee et al., 2012) that provides protection for growth, enabling microorganisms to survive adverse cave environments.

Ideal combination of high grade limestone, the world's highest precipitation, low elevation, and a hot and humid climate have resulted in the formation of Meghalaya's subterranean caves and caverns. The three hills, Khasi, Jaintia, and Garo, contain limestone of variable quantity and quality (Daly, 2009). Knowing the composition of bacterial communities forming the biofilms represents a first approach to understanding the development of bacteria on speleothems, as different bacterial communities can lead to distinct effects on their environment, such as precipitation or dissolution of carbonates in caves (Legatzki et al., 2012; Banerjee and Joshi, 2013; Jones and Bennett, 2014).

Biomineralization is the natural process by which living organisms form minerals from bioorganic molecules and inorganic solids (Bäuerlein, 2004). The living organism provides a chemical environment that controls the nucleation and growth of the mineral phases. Biominerals meet the criteria for being true minerals, but they are often distinguishable from their inorganically produced counterparts by their peculiar shape, size, crystallinity, or isotopic and traceelement compositions (Weiner and Dove, 2003). Bacteria and fungi can induce the precipitation of calcium carbonate extracellularly through a number of processes, including photosynthesis, ammonification, denitrification, sulphate reduction, and anaerobic sulphide oxidation (Riding, 2000). The introduction of new molecular techniques, along with mineralogy techniques such as energy dispersive spectroscopy, enabled the investigation of the complex reactions of microorganisms with minerals (Baskar et al., 2006). Microbes can cause dissolution and precipitation reactions in caves for carbonates, moonmilk, silicates, clays, iron, manganese, sulfur, and saltpeter. They may produce active biogenic influence in the cave formations (Baskar et al., 2009; Li et al., 2014; Daskalakis et al., 2015).

The present study is an attempt to add further information about the complex biofilm associations in the surveyed caves and to provide information about the interaction of bacteria with the geologic substrate. The caves in Meghalaya (locally called $\mathrm{krem}$ ) are not easily accessible, since they are situated in hilly, uninhabited, and remote areas. The present geomicrobiological study is based on five caves, four of which are located in the East Khasi Hills district and one in East Jaintia Hills district of Meghalaya. The caves located in East Khasi Hills district are Mawsmai (N 25⒕68'; E 91 ${ }^{\circ} 43.48^{\prime}$ ), Mawmluh (Mawkhyrdop) (N 25⒖548'; E 91²42.749'),

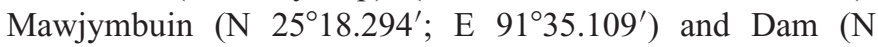
$25^{\circ} 18.491^{\prime}$; E $91^{\circ} 35.496^{\prime}$ ) caves; the cave located in East Jaintia Hills is Labit (N $25^{\circ} 21.16^{\prime}$; E $\left.92^{\circ} 31.0 .23^{\prime}\right)$ cave. The isolated biofilm bacteria were studied with scanning electron microscopy coupled with energy dispersive X-ray analysis for

\footnotetext{
* Corresponding author: srjoshi2006@yahoo.co.in

Microbiology Laboratory, Department of Biotechnology \& Bioinformatics, NorthEastern Hill University, Shillong-793022, Meghalaya, India
} 
in vitro generation of calcium crystals, since calcium precipitation is the predominant form of mineralization involved in speleothem formation, and to analyze whether the chemoheterotrophic bacteria play any role in formation of stalactites, stalagmites, and various cave-wall deposits.

\section{Materials And Methods}

Krem Mawsmai is located south of lower Cherrapunji below a zone thickly forested with pine and broad-leafed trees, the Mawsmai (or locally Mawlongsyiem) sacred forest, which receives very high rainfall. The dense canopy cover of the groves provides an ideal microclimate for the survival of certain species due to the high nutrient release in the soil. The $160 \mathrm{~m}$ long cave is totally aphotic and has plenty of stalactites and stalagmites. The cave was moist, and water dripping from the roof was observed during sampling. Krem Mawmluh, also known as Mawkhyrdop cave, is located at a distance of approximately $1 \mathrm{~km}$ west of Sohra (Cherrapunji), adjacent to the cement factory Mawmluh-Cherra Ltd. and at a distance of $10 \mathrm{~km}$ from Mawsmai cave. The cave is about $7.1 \mathrm{~km}$ long and is the longest cave system in the Khasi Hills. The entrance lies at the bottom of the western flank of the Lum Lawbah, which flows throughout the year and most prominently during monsoons, and is contaminated by effluents from the cement factory. As the sampling time was during the monsoons in the month of July, we could collect biofilm samples only from the cave entrance, rather than venturing inside. Krem Mawjymbuin is situated in Mawsynram in eastern Khasi Hills district of Meghalaya at an elevation of $209 \mathrm{~m}$. Years of weathering and dripping of mineralized solutions have formed magnificent stalagmites of calcum salts. Inside the cave is a pair of notable speleothems that are shaped into a Shivalinga, Hindu mythological god. Krem Dam, measuring $1297 \mathrm{~m}$ in length, lies at the foot of a large blind valley approximately $1 \mathrm{~km}$ to the east of Mawsynram village and is the biggest cave in the entire subcontinent of India that is totally in sandstone. The titanic entranceway approximately $30 \mathrm{~m}$ across is the chief attraction of the cave. The cave consists of a very large river passage ending in a roof collapse where daylight can be seen, but no significant calcite formations are found in this cave. KremLabit is located in NongkhliehElaka (the Shnong Rim area) of east Jaintia Hills district and is a part of the longest cave system in India, Krem Laitprah/Um Im-Labit. The current length of the cave system is approximately $31 \mathrm{~km}$, which is likely to be increased as nearby caves continue to be explored.

Biofilm samples were gently and aseptically scrapped off from areas of the caves minimally disturbed by anthropogenic activities. They were then placed in sterile sample containers and kept in icebox. The samples were immediately brought to the laboratory, kept at $4{ }^{\circ} \mathrm{C}$, and analyzed within 24 hours.

Isolations of bacteria from the speleothems of caves were made to identify the culturable, aerobic, heterotrophic fraction of the total microbial community. Duplicate samples of

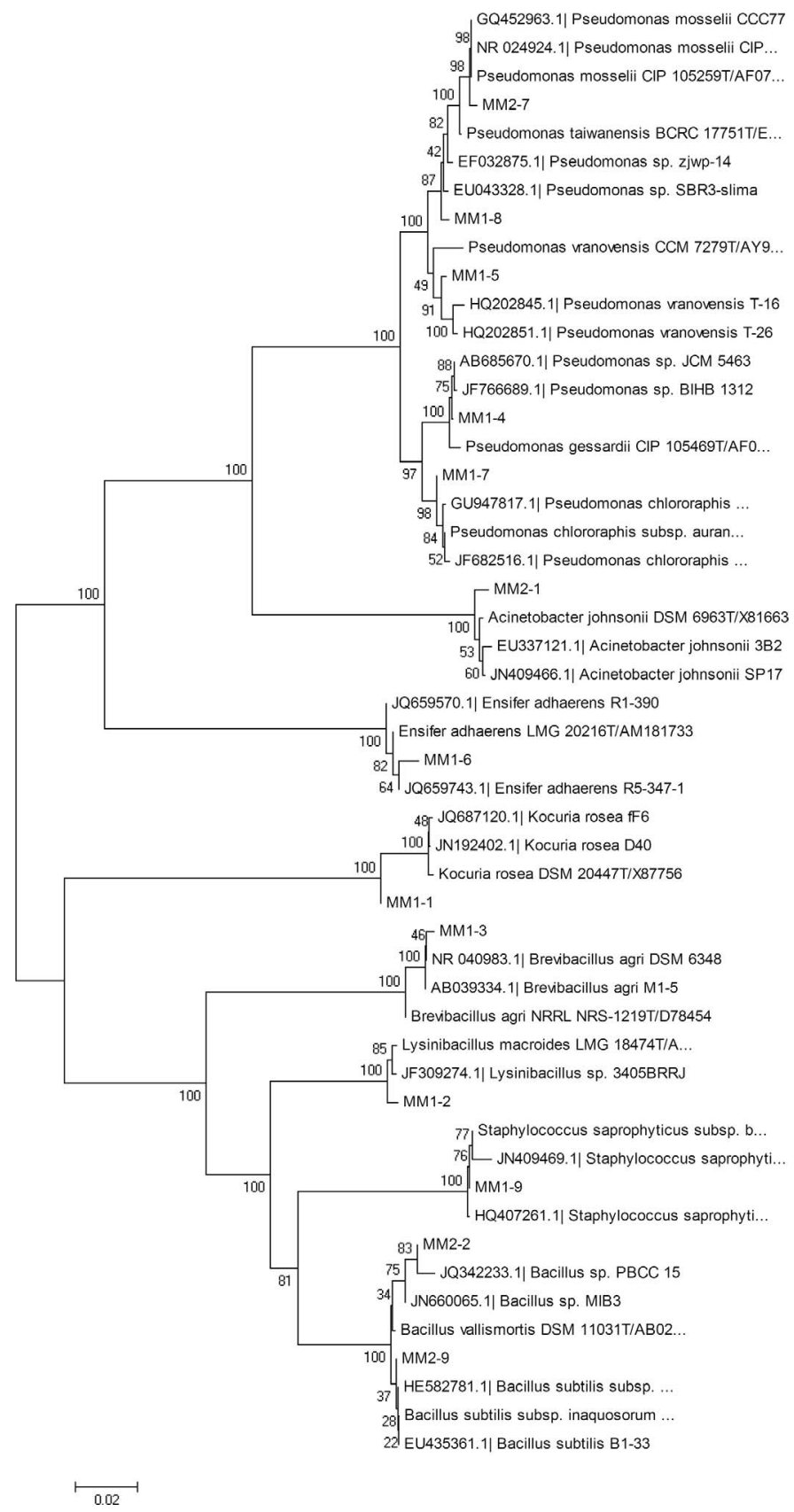

Figure 1. Neighbor-joining tree based on 16S rRNA gene sequences depicting the phylogenetic relationships between the isolates obtained from Krem Mawsmai listed in Table 3. The scale bar corresponds to the expected number of changes per nucleotide position.

biofilm $(1 \mathrm{~g})$ were aseptically transferred into $9 \mathrm{ml}$ sterile Ringer salt solution (SRL, India), 1/4 strength, and vortexed briefly for 2 minutes. Serial 10 -fold dilutions ranging from $10^{-1}$ to $10^{-5}$ were plated in triplicates onto Nutrient Agar and R2A Agar. The plates were incubated at $25{ }^{\circ} \mathrm{C}$ to mimic cave temperatures in an inverted position for 3 days, and the colony-forming units were recorded. Nutrient Agar was used 


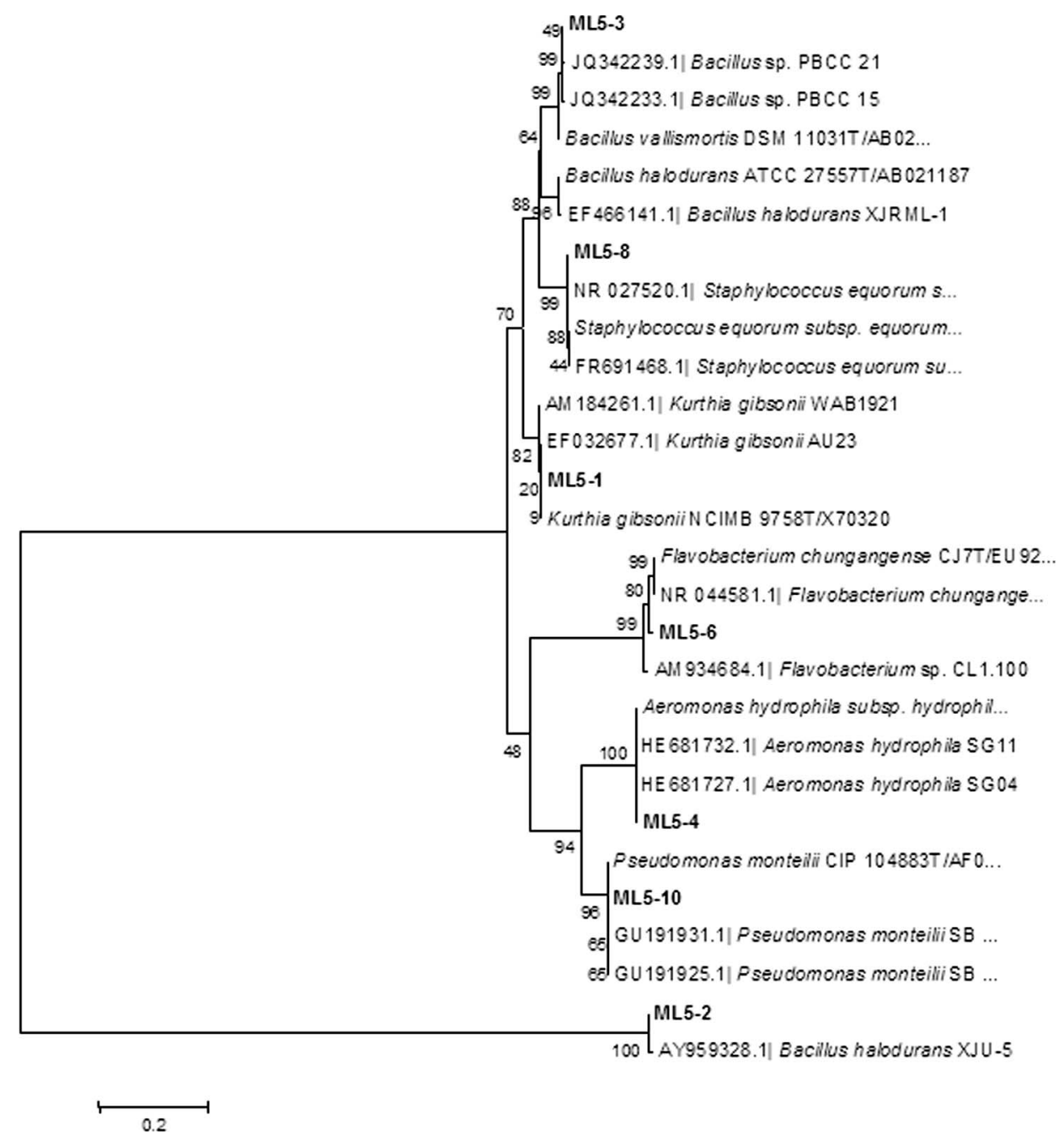

Figure 2. Neighbor-joining tree based on 16S rRNA gene sequences depicting the phylogenetic relationships between the isolates obtained from Krem Mawmluh listed in Table 3. The scale bar corresponds to the expected number of changes per nucleotide position.

as the standard nutrient-rich media, and R2A Agar was used as the minimal media to enumerate the aerobic heterotrophic count (Baskar et al., 2006). Controls consisting of autoclaved distilled water and $0.9 \%$ saline solution were also incubated. Individual colonies were selected based on color and, colony morphotypes and purified by repeated streaking.

The cell shape, size, arrangement, and Gram-staining parameters were observed for all the isolates under a brightfield microscope (Leica DM 5500, Germany). Preliminary identification and characterization were done by morphological and biochemical analysis following Bergey's Manual of Determinative Bacteriology (Holt et al., 2000) using standard protocols.

Genomic DNA isolation was done by Bacterial Genomic DNA Purification Spin Kit (HiMedia, India), followed by amplification of bacterial $16 \mathrm{~S}$ rRNA gene using the universal bacterial $16 \mathrm{~S}$ rRNA primers, 27F [5'-AGA GTT TGA TCC
TGG CTC AG-3'] and 1541R [5'-AAGGAG GTG ATC CAG CCG CA-3'] (Cao et al., 2003). PCR was performed at a final reaction volume of $50 \mu \mathrm{L}$ containing $10 \mathrm{mM}$ Tris- $\mathrm{HCl}, 50 \mathrm{mM}$ $\mathrm{KCl}, 1.5 \mathrm{mM} \mathrm{MgCl}_{2}, 0.25 \mathrm{mM}$ each of deoxynucleoside triphosphates (dATP, dCTP, dGTP, and dTTP), $0.2 \mu \mathrm{M}$ primers, $0.2 \mu \mathrm{L}$ of $3 \mathrm{U} / \mu \mathrm{LTaq}$ DNA polymerase (Bangalore Genei, India), and $3 \mu \mathrm{L}$ of the extracted DNA as template (approximately $150 \mathrm{ng}$ ). The amplification was programmed as initial denaturation for $5 \mathrm{~min}$ at $94{ }^{\circ} \mathrm{C}$, followed by 35 cycles consisting of denaturation at $94{ }^{\circ} \mathrm{C}$ for $1 \mathrm{~min}$, annealing at $55^{\circ} \mathrm{C}$ for $1 \mathrm{~min}$, and elongation at $72{ }^{\circ} \mathrm{C}$ for $2 \mathrm{~min}$, and then cycling was completed by a final elongation step for $5 \mathrm{~min}$ at $72{ }^{\circ} \mathrm{C}$ in a Gene AMP PCR system 9700 (Applied Biosystems, California, USA). A control tube containing sterile water instead of DNA solution was used as a negative control. Results were then purified using QIAquick Gel Extraction Kit (QIAGEN, Germany). Bi-directional sequencing reactions of 


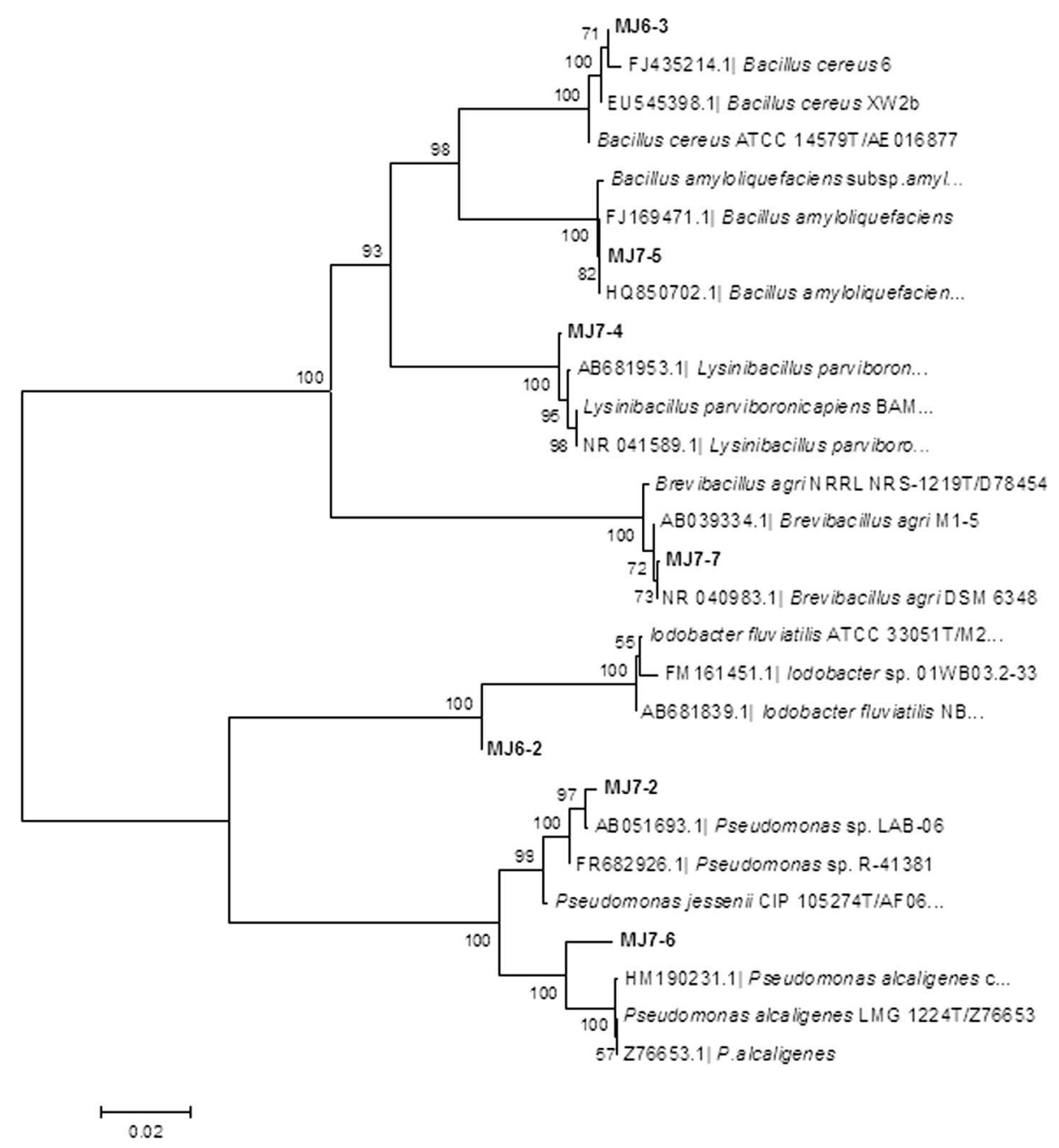

Figure 3. Neighbor-joining tree based on 16S rRNA gene sequences depicting the phylogenetic relationships between the isolates obtained from Krem Mawjymbuin listed in Table 3. The scale bar corresponds to the expected number of changes per nucleotide position.

the $16 \mathrm{~S}$ rDNA fragments were performed using the above forward and reverse primers by genetic analyser ABI 3130XL (Applied Biosystems, USA) with the Big Dye (3.1) terminator protocol. The sequencing reaction was performed with $20 \mu \mathrm{L}$ reaction mixture containing approximately $50 \mathrm{ng}$ of template DNA, 1 pmol of primer, and $8 \mu \mathrm{L}$ of ABI BigDye (Applied Biosystems, USA).

The Basic Local Alignment Search Tool (BLAST) was used initially to determine phylogenetic neighbors from the nucleotide database of the National Centre for Biotechnology Information (NCBI) (Altschul et al., 1997). For the isolates selected for the present investigation, the phylogenetic neighbors were obtained using the BLAST program against the database of type strains with manually curated and validly published prokaryotic names on the EzTaxon-e server at http://eztaxon-e.ezbiocloud.net/ (Kim et al., 2012). Molecular Evolutionary Genetics Analysis software (MEGA version 4) was used for phylogenetic analyses (Tamura et al., 2007). The sequences of identified phylogenetic neighbors were aligned with the sequences of representative strains by using the CLUSTAL $\mathrm{W}$ routine built into MEGA 4. The neighborjoining method was employed to construct the phylogenetic tree with 1000 bootstrap replications to assess nodal support in the tree (Felsenstein, 1985). The nucleotide sequences were then deposited in NCBI database and accession numbers obtained.

The bacterial isolates were spot-inoculated on B4 agar (2.5 $\mathrm{g} \mathrm{L}^{-1}$ calcium acetate, $4 \mathrm{~g} \mathrm{~L}^{-1}$ yeast extract, $10 \mathrm{~g} \mathrm{~L}^{-1}$ glucose and $18 \mathrm{~g} \mathrm{~L}^{-1}$ agar) for detection of calcite (calcium carbonate) precipitation (Boquet et al., 1973). Controls consisted of uninoculated culture medium and medium inoculated with autoclaved, dead bacterial cells. The plates were incubated aerobically at $25^{\circ} \mathrm{C}$ to mimic cave temperatures in an inverted position and each isolate was periodically examined up to 25 days for the presence of crystals (Banerjee and Joshi, 2014).

Journal of Cave and Karst Studies, December 2016 • 147 


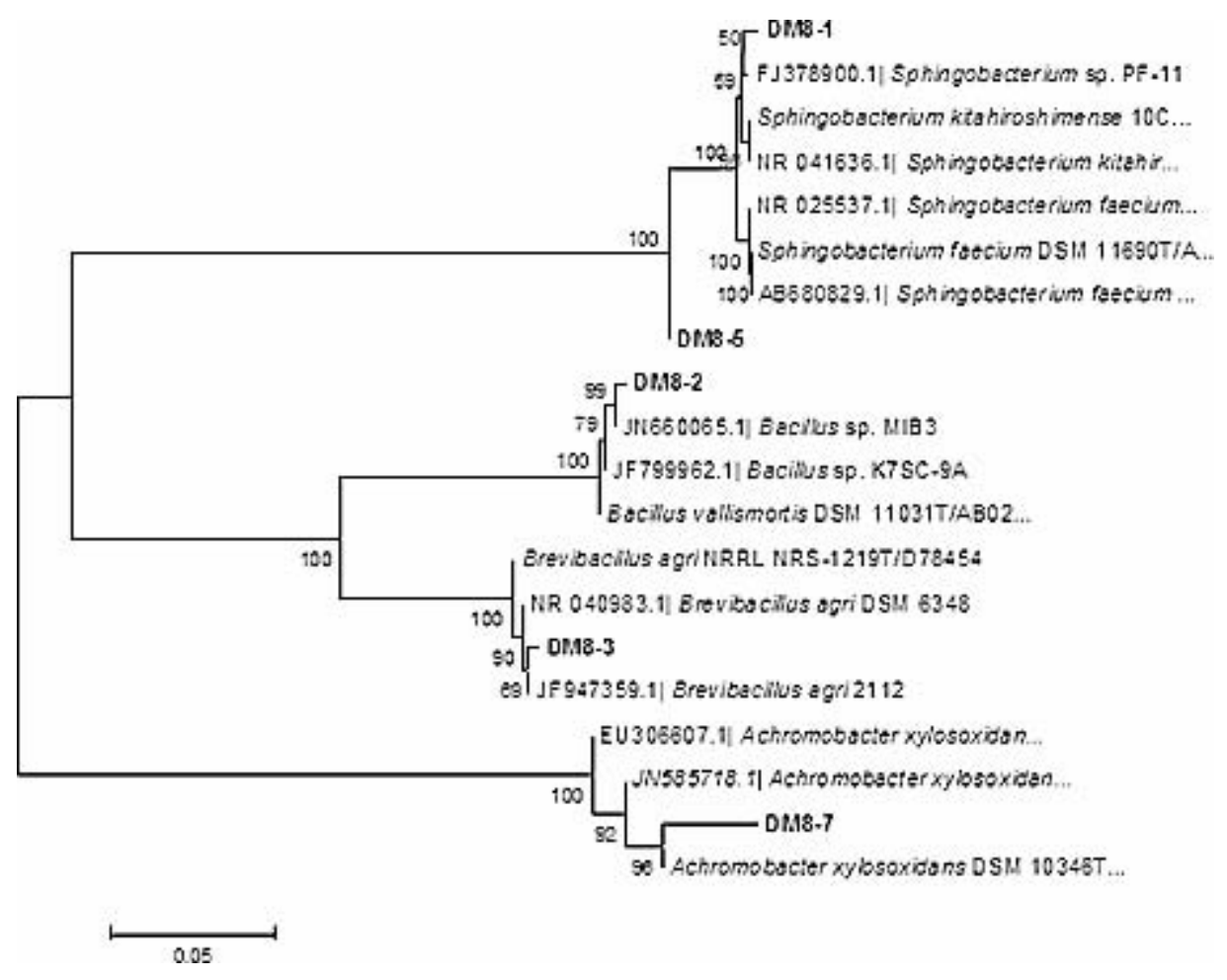

Figure 4. Neighbor-joining tree based on 16S rRNA gene sequences depicting the phylogenetic relationships between the isolates obtained from Krem Dam listed in Table 3. The scale bar corresponds to the expected number of changes per nucleotide position.

The crystal-precipitating cultures were aseptically excised from the media. Morphology and size characteristics of both the crystals and the microorganisms were studied by scanning electron microscopy (JSM 6360 [JEOL], resolution $3 \mathrm{~nm}$, magnification $8 \times$ through $300,000 \times$, accelerating voltage, 1 $30 \mathrm{kV})$. SEM samples were prepared as follows: agar blocks of cultures grown on B4 medium were fixed onto aluminum stubs with two-way adherent tabs with conductive paint and allowed to dry. They were then gold-coated by sputtering for approximately $2 \mathrm{~min}$ to $3 \mathrm{~min}$, dried at $37{ }^{\circ} \mathrm{C}$, and gold shadowed (Baskar et al., 2009). The SEM was equipped with an energy dispersive X-ray (EDX) analyzer (INCA Penta FET X3 Model 7582, Oxford Instruments, England) with a resolution at $5.9 \mathrm{KeV}$ of $133 \mathrm{eV}$. That instrument was used to examine microbial colonies for their cells, filaments, or biofilms, and the microstructures and mineral compositions of associated crystals.

SEM studies were also performed on a few representative speleothems from Krem Mawsmai and Krem Mawmluh. EDX was used for quantitative estimation of the chemical composition of the minerals involved in the cave deposits following the same procedures as previously described for examination of crystals. The data generated by EDX analysis consisted of spectra showing peaks corresponding to the elements making up the true composition of the sample being analyzed.

\section{RESULTS}

Bacteria with diverse morphologies and cultural characteristics were observed on dilution plates from each cave. Gram staining showed the presence of both Gram-positive and Gram-negative bacteria. Pure cultures of the bacterial strains showed marked variation in colony morphology and pigmentation. The isolated bacteria were identified mostly to genus level and some to species level with the aid of biochemical tests.

The isolates identified to genus level through biochemical tests were further characterized to species level using molecular techniques. The PCR products of 16S rRNA were sequenced. The sequences of these isolates were aligned with the database of EzTaxon-e. Five different phylogenetic trees, one for each cave studied, were constructed using NeighborJoining method in Mega 4.1 software (Figs. 1-5). Table 1 lists the bacterial isolates identified from the studied caves. Table 2 summarizes the bacteria isolated and identified by both biochemical and molecular approaches, grouped by higher divisions.

The 16S rRNA partial sequences were deposited to the National Centre for Biotechnology Information GenBank under the GenBank IDs JX040437-JX040447, JX144942JX144954, JX144956-JX144960, JX298811, JX298812, and KF515731-KF515736 (Table 3). 
Table 1. Bacterial isolates identified from the studied caves.

Caves

\begin{tabular}{|c|c|c|c|c|c|}
\hline Isolates & Mawsmai & Mawmluh & Mawjymbuin & Dam & Labit \\
\hline Bacillus subtilis & + & - & - & - & - \\
\hline Bacillus cereus & - & - & + & - & + \\
\hline Bacillus vallismortis & + & - & - & - & - \\
\hline Bacillus halodurans & - & + & - & - & - \\
\hline Bacillus amyloliquefaciens & - & - & + & - & - \\
\hline Bacillus thuringiensis & - & - & - & - & + \\
\hline Bacillus circulans & - & - & - & - & + \\
\hline Bacillus isronensis & - & - & - & - & + \\
\hline Bacillus sp. & - & - & - & + & - \\
\hline Pseudomonas gessardii & + & - & - & - & - \\
\hline Pseudomonas vranovensis & + & - & - & - & - \\
\hline Pseudomonas chlororaphis & + & - & - & - & - \\
\hline Pseudomonas taiwanensis & + & - & - & - & - \\
\hline Pseudomonas mosselii & + & - & - & - & - \\
\hline Pseudomonas monteilii & - & + & - & - & - \\
\hline Pseudomonas alcaligenes & - & - & + & - & - \\
\hline Pseudomonas sp. & - & - & + & - & - \\
\hline Kocuria rosea & + & - & - & - & - \\
\hline Lysinibacillus macroides & + & - & - & - & - \\
\hline Lysinibacillus parviboronicapiens & - & - & + & - & - \\
\hline Brevibacterium frigoritolerans & - & - & - & - & + \\
\hline Brevibacillus agri & + & - & + & + & - \\
\hline Paenibacillus massiliensis & - & - & - & - & + \\
\hline Ensifer adhaerens & + & - & - & - & - \\
\hline Achromobacter xylosoxidans & - & - & - & + & - \\
\hline Staphylococcus saprophyticus & + & - & - & - & - \\
\hline Staphylococcus equorum & - & + & - & - & - \\
\hline Sphingobacterium faecium & - & - & - & + & - \\
\hline Sphingobacterium kitahiroshimense & - & - & - & + & - \\
\hline Acinetobacter johnsonii & + & - & - & - & - \\
\hline Iodobacter fluviatilis & - & - & + & - & - \\
\hline Kurthia gibsonii & - & + & - & - & - \\
\hline Aeromonas hydrophila & - & + & - & - & - \\
\hline Flavobacterium chungangense & - & + & - & - & - \\
\hline
\end{tabular}

The overall structure of the selected bacteria and various crystal morphologies associated with them were clearly evident when examined under the electron microscope. SEM photomicrographs showed the presence of calcite crystals of various sizes, and most strikingly, a significant number of nanoscale to microscopic-size calcite crystals (Fig. 6). In addition, biofilms that were interwoven throughout the fiber network and bacterial filaments were observed under the SEM. Furthermore, EDX analyses confirmed that the crystals were composed predominately of calcium, carbon, and oxygen, suggesting precipitation solely of calcite and not of any other compound (Fig. 7).

Electron-microscopy studies of the speleothem samples were also done to investigate if the crystals generated by the isolated bacteria in vitro and the microorganisms themselves form a part and parcel of the speleothem itself, thereby to confirm the biogenic role, if any, in cave formations. All the observed structures, coupled with the highly weathered and disintegrated crystals of calcite, organic inclusions, and lithified structures indicated that they may have been formed by the metabolic activities of the associated bacterial communities (Fig. 8). The high concentration of carbon and oxygen as evidenced by EDX in the original cave wall and cultured samples may possibly reflect the visible microbial colonization of the cave walls. EDX of the speleothems revealed that apart from calcium, oxygen, and carbon expected for calcite, traces of deposits of magnesium, silica, iron, scandium, and tellurium were are also present (Figs. 9, 10).

Journal of Cave and Karst Studies, December 2016 • 149 
Table 2. Phyla and classes of genera identified by biochemical and 16S rRNA gene sequencing.

\begin{tabular}{lll}
\hline Phylum & \multicolumn{1}{c}{ Class } & \multicolumn{1}{c}{ Genus } \\
\hline Firmicutes & Bacilli & $\begin{array}{l}\text { Bacillus } \\
\text { Brevibacillus } \\
\text { Lysinibacillus } \\
\text { Paenibacillus }\end{array}$ \\
& & Staphylococcus \\
& & Kurthia \\
Bacteroidetes & Sphingobacteria & Sphingobacterium \\
& Flavobacteria & Flavobacterium \\
Actinobacteria & Actinobacteria & Kocuria \\
& & Brevibacterium \\
Proteobacteria & Alpha & Ensifer \\
& Beta & Achromobacter \\
& & Iodobacter \\
& Gamma & Aeromonas \\
& & Acinetobacter \\
& & Pseudomonas \\
\hline
\end{tabular}

\section{DiSCUSSION}

Despite numerous studies performed to determine the mechanisms of biomineralization, the precise biomineral formation mechanisms remain uncertain. The geomicrobiology of subsurface rock environments of Meghalaya in NorthEast India has lacked investigation and understanding, even though the state hosts some of the longest caves in the Indian sub-continent and could provide useful information on general and applied microbiology as well as geosciences. Analysis of microbial communities, their role in biomineralization processes and their geomicrobiological interactions can help to understand the steps of colonization, subsurface microbial diversity, biomineral diversity, and various biomineralization mechanisms. Research on the role of microbial species in the development of secondary carbonate deposits in caves is still going on. Irrespective of the pathway, bacterial metabolic activity in these environments appears to lead to the precipitation of various polymorphs of $\mathrm{CaCO}_{3}$, suggesting that bacterial metabolism plays a dominant role in calcification processes (Banks et al., 2010). Bacteria may also act as highly reactive geochemical interfaces, and their extracellular polymers are especially effective at binding ions from solution and serving as nucleation surfaces for mineral formation (Merz, 1992). These metabolic activities of microbes can, therefore, induce localized conditions that are favorable for mineral precipitation

The study revealed different indigenous chemoheterotrophic bacterial strains from five caves of Meghalaya, with the predominant bacterial genera belonging to Bacillus and Pseudomonas, which is in accordance with other studies where Bacillus is the predominant genera involved in calciumcarbonate precipitation (Baskar et al., 2009). In the present
Table 3. Closest match of the bacterial isolates based on $16 \mathrm{~S}$ rRNA gene phylogeny analysis.

\begin{tabular}{|c|c|c|}
\hline Isolates & $\begin{array}{c}\text { GenBank } \\
\text { Accession } \\
\text { Number }\end{array}$ & Closest Related Microorganism \\
\hline DM8-1 & JX040437 & $\begin{array}{l}\text { Sphingobacterium } \\
\text { kitahiroshimense }\end{array}$ \\
\hline DM8-2 & JX040438 & Bacillus sp. \\
\hline DM8-3 & JX040439 & Brevibacillus agri \\
\hline DM8-5 & JX040440 & Sphingobacterium faecium \\
\hline DM8-7 & JX040441 & Achromobacter xylosoxidans \\
\hline MJ6-2 & JX040442 & Iodobacter fluviatilis \\
\hline MJ6-3 & JX040443 & Bacillus cereus \\
\hline MJ7-2 & JX040444 & Pseudomonas sp. \\
\hline MJ7-7 & JX040445 & Brevibacillus agri \\
\hline MJ7-4 & JX040446 & Lysinibacillus parviboronicapiens \\
\hline MJ7-5 & JX040447 & $\begin{array}{l}\text { Bacillus amyloliquefaciens subsp. } \\
\text { amyloliquefaciens }\end{array}$ \\
\hline MM1-1 & JX144942 & Kocuria rosea \\
\hline MM1-2 & JX144943 & Lysinibacillus macroides \\
\hline MM1-3 & JX144944 & Brevibacillus agri \\
\hline MM1-4 & JX144945 & Pseudomonas gessardii \\
\hline MM1-5 & JX144946 & Pseudomonas vranovensis \\
\hline DM8-1 & JX040437 & $\begin{array}{l}\text { Sphingobacterium } \\
\text { kitahiroshimense }\end{array}$ \\
\hline MM1-7 & JX144947 & $\begin{array}{l}\text { Pseudomonas chlororaphis subsp. } \\
\quad \text { aurantiaca }\end{array}$ \\
\hline MM1-8 & JX144948 & Pseudomonas taiwanensis \\
\hline MM1-9 & JX144949 & $\begin{array}{l}\text { Staphylococcus } \\
\quad \text { saprophyticussubsp. bovis }\end{array}$ \\
\hline MM2-1 & JX144950 & Acinetobacter johnsonii \\
\hline MM2-2 & JX144951 & Bacillus vallismortis \\
\hline MM2-7 & JX144952 & Pseudomonas mosselii \\
\hline MM2-9 & JX144953 & $\begin{array}{l}\text { Bacillus subtilis subsp. } \\
\quad \text { inaquosorum }\end{array}$ \\
\hline ML5-1 & JX144954 & Kurthia gibsonii \\
\hline ML5-4 & JX144956 & $\begin{array}{l}\text { Aeromonas hydrophila subsp. } \\
\text { hydrophila }\end{array}$ \\
\hline ML5-6 & JX144957 & Flavobacterium chungangense \\
\hline ML5-8 & JX144958 & $\begin{array}{l}\text { Staphylococcus equorumsubsp. } \\
\text { equorum }\end{array}$ \\
\hline ML5-10 & JX144959 & Pseudomonas monteilii \\
\hline MJ7-6 & JX144960 & Pseudomonas alcaligenes \\
\hline MM1-6 & JX298811 & Ensifer adhaerens \\
\hline ML5-2 & JX298812 & Bacillus halodurans \\
\hline LB1 & KF515731 & Bacillus thuringiensis \\
\hline LB2 & KF515732 & Bacillus circulans \\
\hline LB3 & KF515733 & Paenibacillus massiliensis \\
\hline LB4 & KF515734 & Brevibacterium frigoritolerans \\
\hline LB5 & KF515735 & Bacillus isronensis \\
\hline LB6 & KF515736 & Bacillus cereus \\
\hline
\end{tabular}




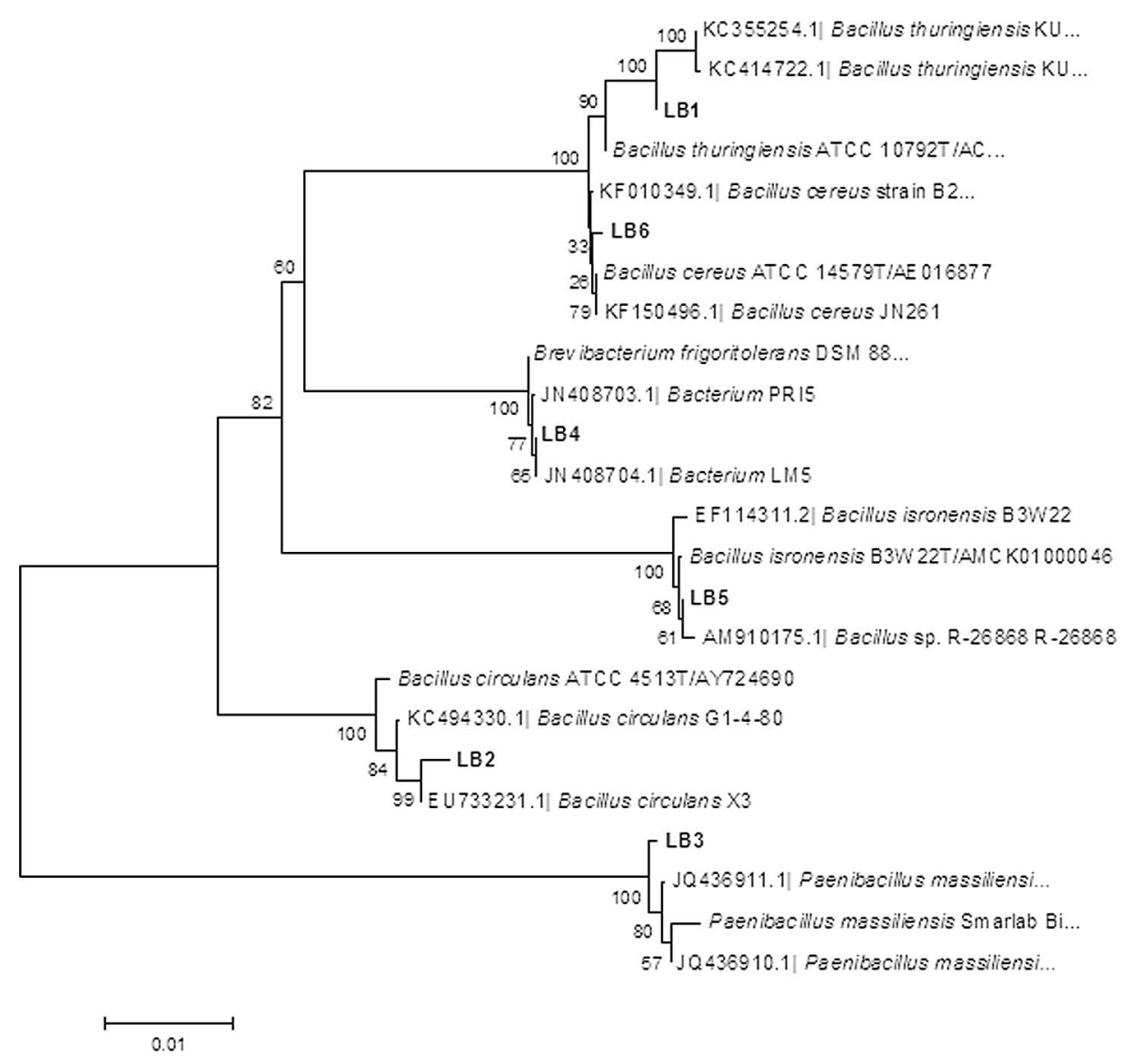

Figure 5. Neighbor-joining tree based on 16S rRNA gene sequences depicting the phylogenetic relationships between the isolates obtained from Krem Labit listed in Table 3. The scale bar corresponds to the expected number of changes per nucleotide position.

study, it was determined that a few genera are prevalent in one cave but absent in the other selected sampling sites. The prevalence of Sphingobacterium in Krem Dam only can shed some light on the uniqueness of this organism to adjust itself in this yet untouched cave. On the other hand, diverse species of Pseudomonas encountered in Krem Mawjymbuin can be related to their versatile nature and ability to form biofilm. From the various phyla obtained in the present study, it was evident that bacteria belonging to phylum Firmicutes predominated in all the caves studied except in Krem Mawsmai, where the predominant bacteria belonged to Gammaproteobacteria. Studies have shown that Gammaproteobacteria were found to be important biofilm-forming groups in Lower Kane Cave, Wyoming, and Movile Cave, Romania (Engel et al., 2001, 2003). Such results led the investigators to conclude that the surface of the Gammaproteobacteria species found within the bacterial filaments of the cave played a crucial role in calcite deposition (Holmes et al., 2001). Moreover, this group of bacteria are commonly present as yellow biofilms in oxygen-deprived microenvironments where the fermentation of organic matter by Gammaproteo- bacteria is known to induce acidification of the medium (Madigan et al., 2003). It was also striking to note that bacteria belonging to Alphaproteobacteria were encountered only in Krem Mawsmai, which could be attributed to the nature and anthropogenic influences prevalent in the cave. Moreover, the present findings show that a particular assemblage of bacteria may predominate in a particular cave but be completely absent in other caves, and this observation needs to be investigated in detail for understanding the geomicrobiologal contributions to formation of cave speleothems.

Complex microbial communities producing colored colonizations on Altamira Cave walls in Spain have been reported, with white, yellow, and gray biofilms having been analyzed and distinguished based on the bacterial communities forming these colonizations (Portillo et al., 2009). In addition, a morphological study has been reported on the characteristics of these differently colored biofilms that suggests that white and gray biofilms were associated with mineral deposits, while yellow colonies did not present associated mineral formations (Cuezva et al., 2009). The different coloration of these biofilms is the result of their distinctive composition of bacterial phylotypes

Journal of Cave and Karst Studies, December 2016 • 151 

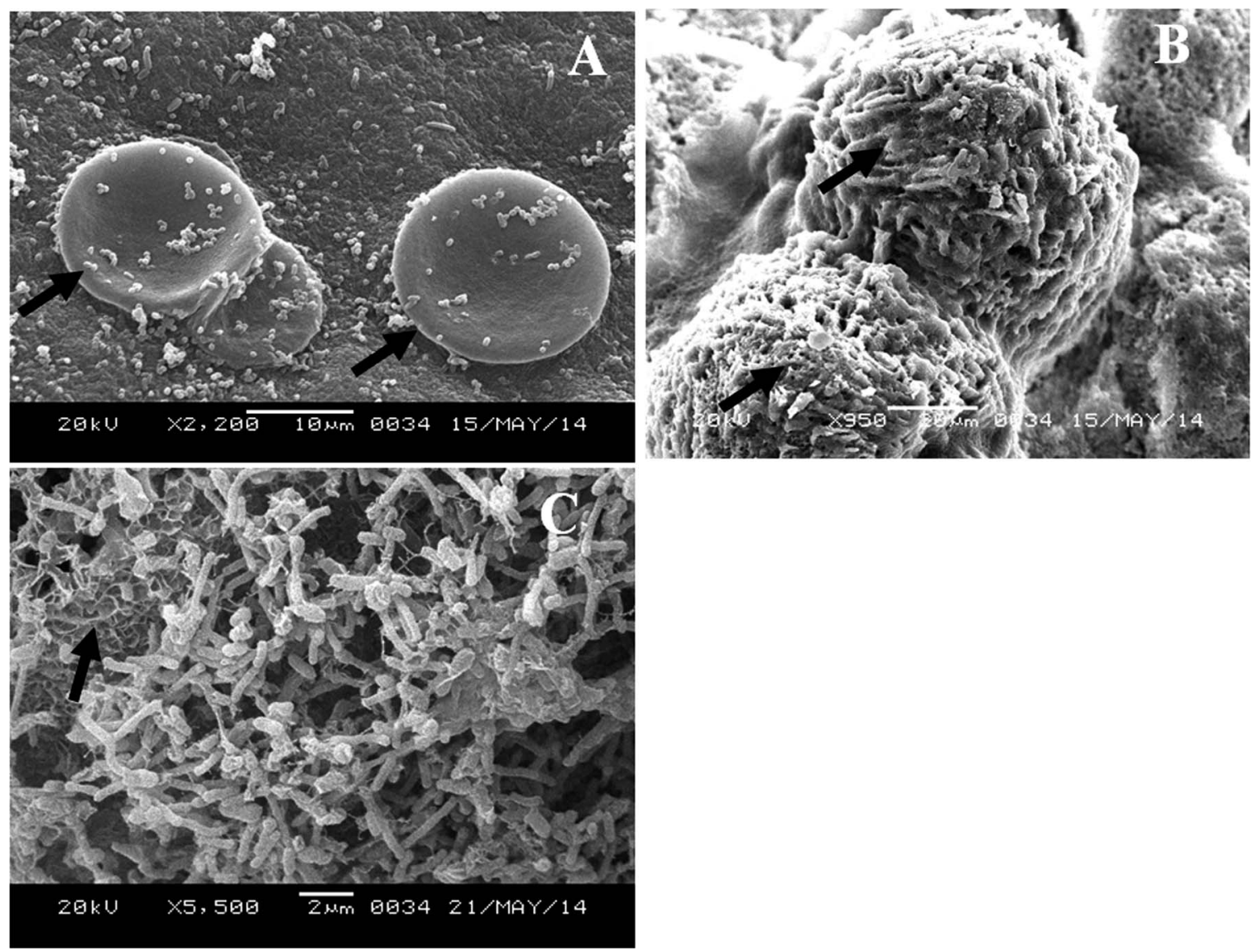

Figure 6. SEM photomicrographs showing varied morphologies of in vitro crystal formation by selected bacterial genera. (A) Numerous bacterial cells of Kurthia gibsonii isolated from a stalagmite in Krem Mawmluh across the disc shaped crystals generated by them. (B) The close association between microbial growth and the precipitation of minerals, including cellshaped pits and septa on the porous hemispherical crystal as indicated by arrows generated by Pseudomonas gessardi isolated from a stalagmite in Krem Mawsmai. (C) A mesh of bacterial ligaments and filaments in association with micro- and nanosized crystals in case of Brevibacterium frigoritolerans isolated from a cave-wall deposit of Krem Labit.

(Portillo et al., 2009). The consequences of bacterial metabolism represent an important aspect to be monitored during the assessments of conservation strategies and the evaluation of potential for the transformation of cave environments.

Electron-microscopy studies of the speleothem samples were done to investigate if crystals similar to those generated in vitro by isolated bacteria and the microorganisms themselves form a part of the speleothems, thereby to confirm the biogenic role, if any, in the formation of the studied caves. The strains were tested for their ability to precipitate calcium carbonate. The presence of crystals and their microscopic sizes were related to bacterially mediated precipitation.

\section{CONCLUSION}

Based on our microbiological observations and SEM-EDX studies, the isolated biofilm bacteria from the studied caves are able to precipitate minerals, thus reaffirming the role of these microorganisms in biospeleogenesis. The results ob- tained in this study indicate a geomicrobiological contribution in the precipitation of calcium carbonate. Similarly, this interpretation could be extended to some other elements that would be specific to a hypogean environment. Further work should be focused toward deciphering the underlying molecular mechanisms behind these complex mineralogical features and microbial assemblages.

\section{ACKNOWLEDGEMENTS}

Authors acknowledge the grant received from Department of Electronics \& Information Technology (DeitY), Government of India, in the form of a research project. Authors thank Sophisticated Analytical Instrument Facility (SAIF), NorthEastern Hills University, Shillong for providing the SEMEDX services. SB would also like to acknowledge the financial assistance received from DST-PURSE programme of NEHU, Shillong. 


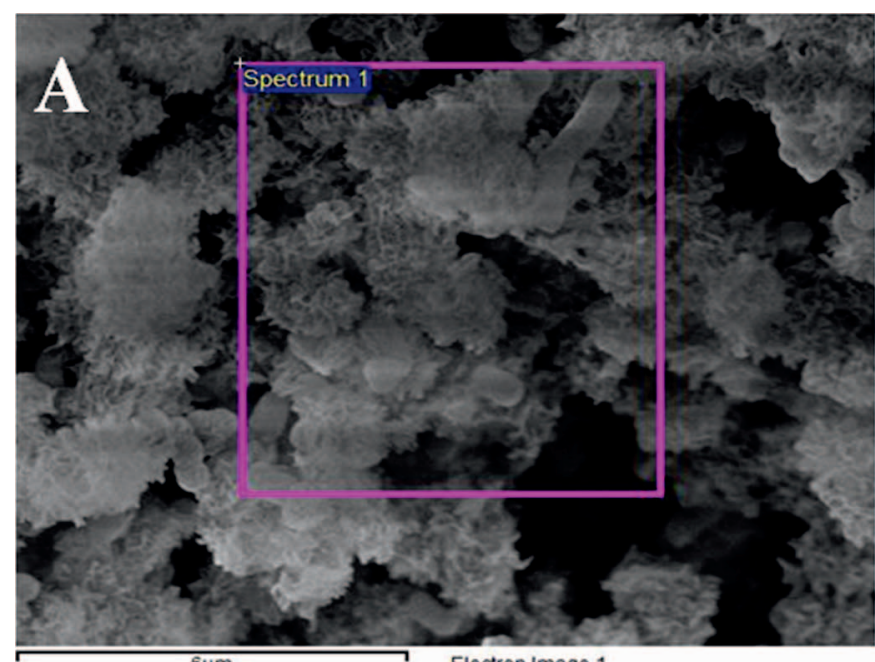

$6 \mu \mathrm{m}$

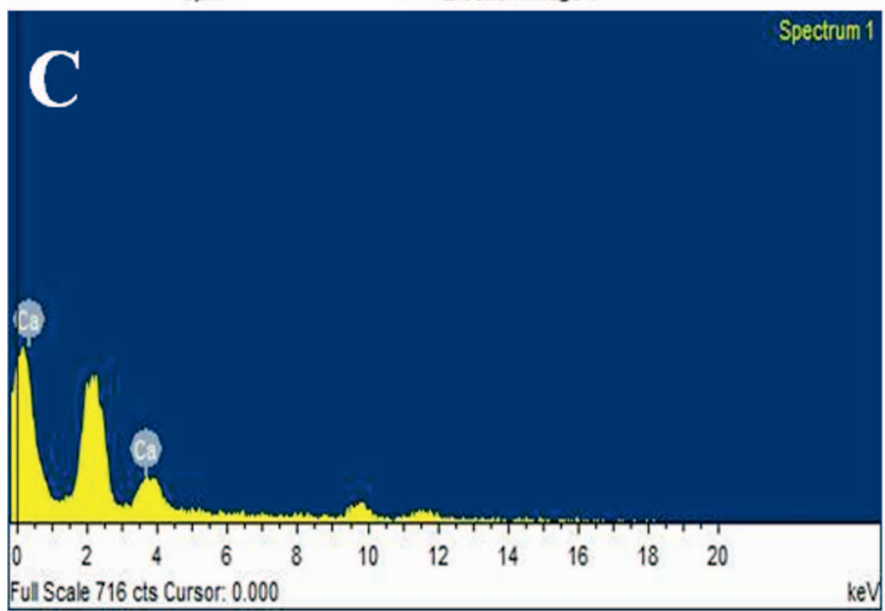

$\mathrm{kel}$

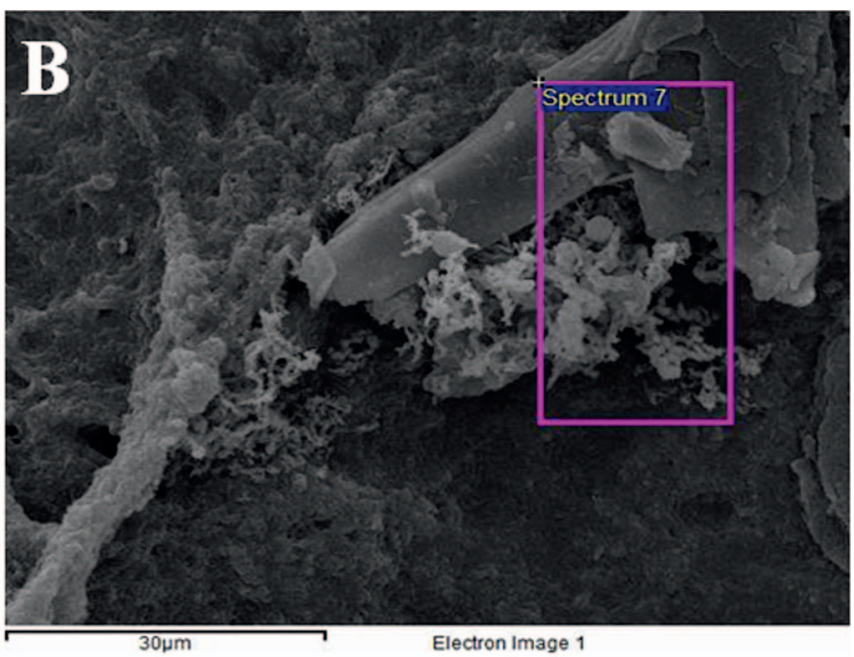

Electron Image 1

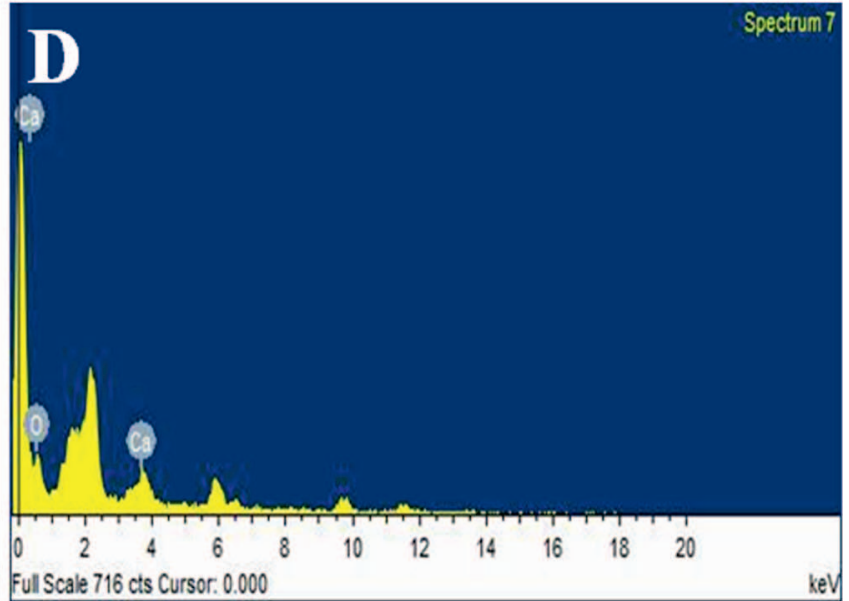

$\mathbf{E}$

\begin{tabular}{|ccc|ccc|}
\hline \multicolumn{3}{|c|}{ Spectrum 1 } & \multicolumn{3}{c|}{ Spectrum 7 } \\
\hline Element & Weight \% & Atomic \% & Element & Weight \% & Atomic \% \\
Ca K & 100 & 100 & OK & 86.69 & 94.22 \\
Totals & 100 & & Ca K & 13.31 & 5.78 \\
& & & Totals & 100 & \\
\hline
\end{tabular}

Figure 7. SEM-EDX of a few crystal polymorphs formed in vitro by Kurthia and Pseudomonas. (A) Fluffy irregular crystals and (B) rhombohedral crystals precipitated by bacteria. (C) EDX showing composition of Spectrum 1 in (A). (D) EDX showing composition of Spectrum 7 in (B). (E) Semiquantitative analysis of the EDX spectra of precipitated crystals of calcite by bacteria. The symbol " $K$ " signifies electron shell of the elements. 

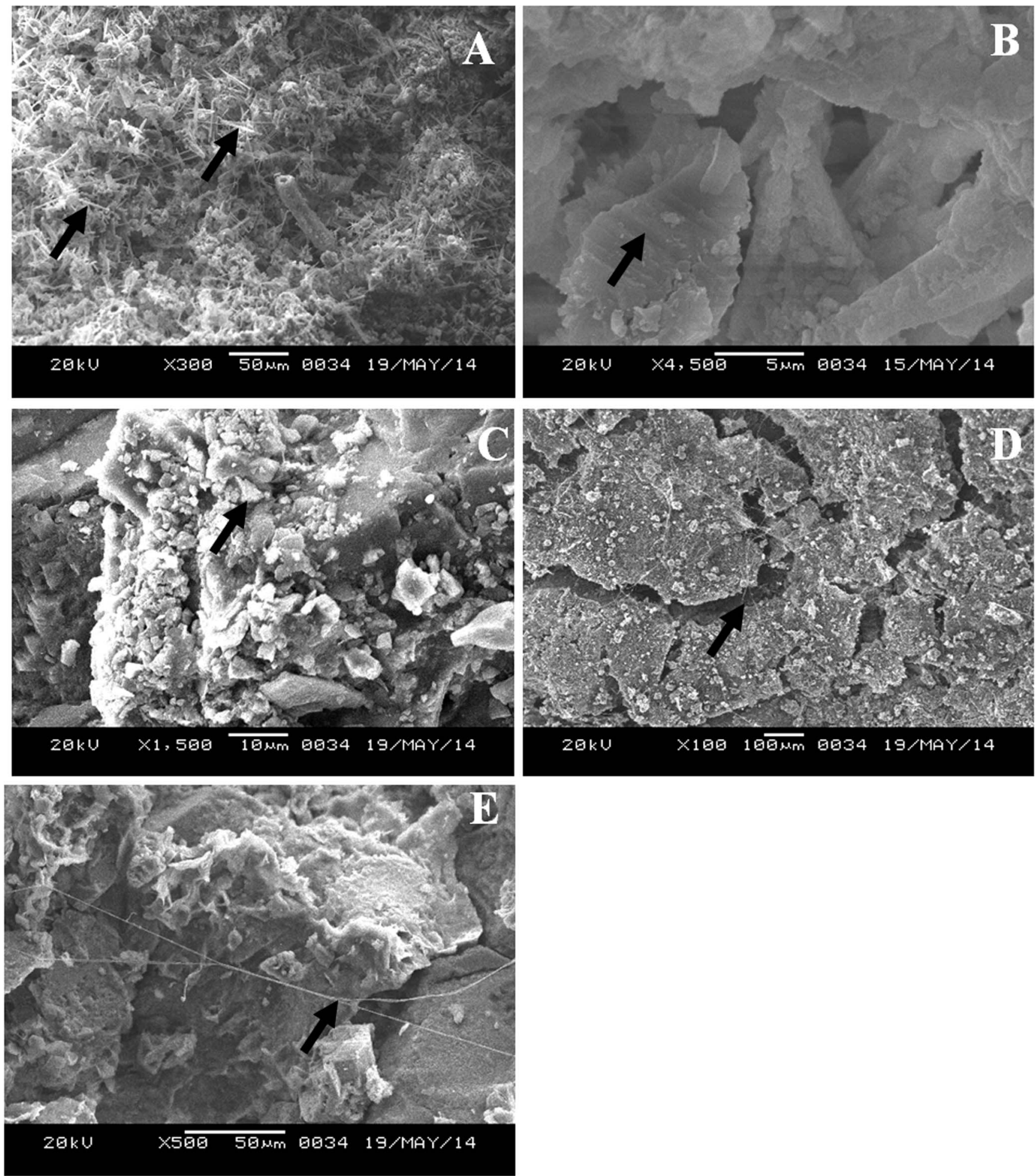

Figure 8. SEM photomicrographs of speleothem samples from the studied caves. (A) Abundant needle-fiber calcites and (B) internal weathered structures of precipitates from Krem Mawsmai speleothems. (C) Calcite crystals observed from Krem Mawmluh speleothems that are similar in pattern to those generated by isolated bacteria. (D) A large aggregate of the individual bioliths binding with nonglobular carbonate bridges in Krem Mawjymbuin speleothems. (E) A large interconnected microbial fiber associated with Krem Dam speleothems. 

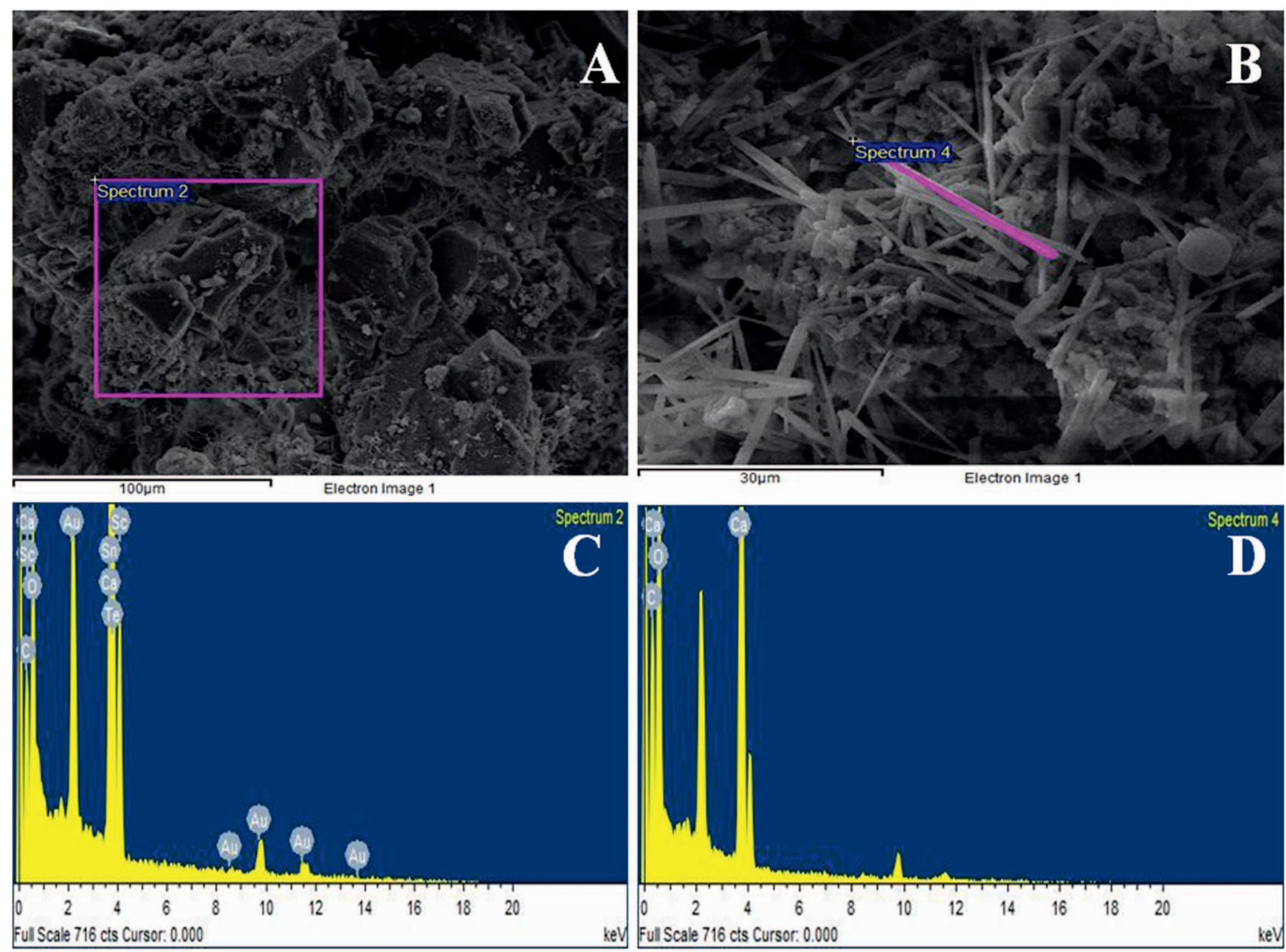

E

\begin{tabular}{|ccc|ccc|}
\hline \multicolumn{2}{|c|}{ Spectrum 2 } & \multicolumn{3}{c|}{ Spectrum 4 } & \\
\hline Element & Weight\% & Atomic\% & Element & Weight\% & Atomic\% \\
C K & 9.35 & 20.24 & C K & 14.29 & 21.01 \\
O K & 33.31 & 54.16 & O K & 62.18 & 68.62 \\
Ca K & 32.68 & 21.2 & Ca K & 23.53 & 10.37 \\
Sc K & 0.67 & 0.38 & Totals & 100 & \\
Sn L & 1.22 & 0.27 & & & \\
Te L & 10.32 & 2.1 & & & \\
An M & 12.45 & 1.64 & & & \\
Totals & 100 & & & & \\
\hline
\end{tabular}

Figure 9. SEM photomicrographs and EDX spectra of speleothem samples from Krem Mawsmai. (A) Presence of spiky calcite, rounded balls of calcite, and microbial filaments. (B) Abundant large needle fiber calcites. (C) Composition of Spectrum 2 in (A). (D) Composition of Spectrum 4 in (B). (E) Semiquantitative analysis of speleothem spectra (C) and (D). The symbol " $K$ " signifies electron shell of the elements. 

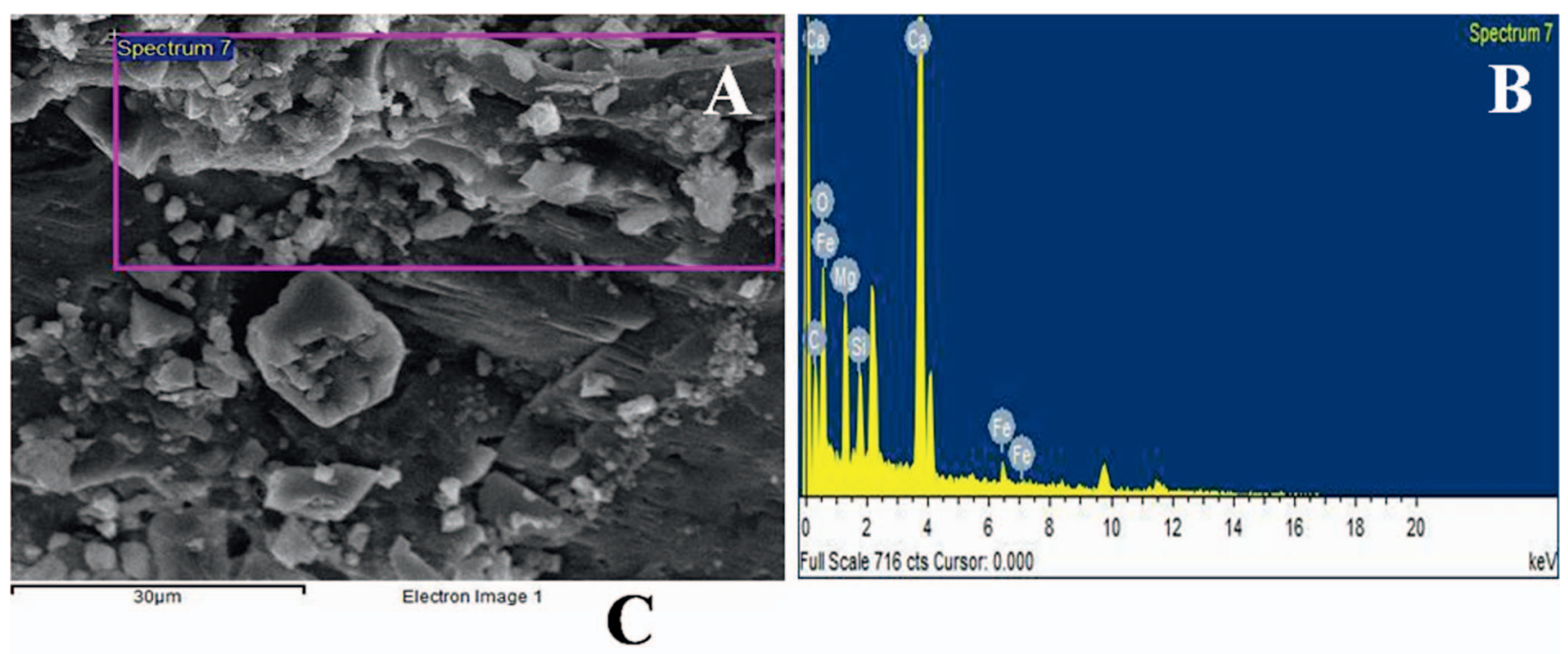

\begin{tabular}{|ccc|}
\hline \multicolumn{2}{|c|}{ Spectrum 7 } \\
\hline Element & Weight\% & Atomic\% \\
$\mathrm{C} \mathrm{K}$ & 14.7 & 23.79 \\
$\mathrm{OK}$ & 44.65 & 54.26 \\
$\mathrm{Mg} \mathrm{K}$ & 6.24 & 4.99 \\
$\mathrm{Si} \mathrm{K}$ & 2.52 & 1.74 \\
$\mathrm{CaK}$ & 30.06 & 14.58 \\
Fe K & 1.83 & 0.64 \\
Totals & 100 & \\
\hline
\end{tabular}

Figure 10. SEM photomicrograph and EDX spectrum of a speleothem sample from Krem Mawmluh. (A) Rhombohedral crystals of calcite accompanied by biofilm and microbial filaments. (B) Composition of Spectrum 7 in (A). (C) Semiquantitative analysis of speleothem spectrum (B). The symbol " $K$ " signifies electron shell of the elements.

\section{REFERENCES}

Altschul, S.F., Madden, T.L., Schäffer, A.A., Zhang, Jinghui, Zhang Zheng, Miller W., and Lipman, D.J., 1997, Gapped BLAST and PSI-BLAST: a new generation of protein database search programs: Nucleic Acids Research, v. 25, p. 3389-3402. doi:10.1093/nar/25.17.3389.

Banerjee, S., Rai, S., Sarma, B., and Joshi, S.R., 2012, Bacterial biofilm in water bodies of Cherrapunjee: the rainiest place on planet earth: Advances in Microbiology, v. 2, p. 465-475. doi:10.4236/aim.2012.24060.

Banerjee, S., and Joshi, S.R., 2013, Insights into cave architecture and the role of bacterial biofilm: Proceedings of the National Academy of Sciences, India Section B: Biological Sciences, v. 83, p. 277-290. doi:10.1007/ s40011-012-0149-3.

Banerjee, S., and Joshi, S. R., 2014, Ultrastructural analysis of calcite crystal patterns formed by biofilm bacteria associated with cave speleothems: Journal of Microscopy and Ultrastructure, v. 2, p. 217-223. doi:10.1016/j. jmau.2014.06.001.

Banks, E.D., Taylor, N.M., Gulley, J., Lubbers, B.R., Giarrizo, J.G., Bullen, H.A., Hoehler, T.M., and Barton, H.A., 2010, Bacterial calcium carbonate precipitation in cave environments: a function of calcium homeostasis:
Geomicrobiology Journal, v. 27, p. 444-454. doi:10.1080/ 01490450903485136.

Baskar, S., Baskar, R., Mauclaire, L., and McKenzie, J.A., 2006, Microbially induced calcite precipitation in culture experiments: possible origin for stalactites in Sahastradhara caves, Dehadrun, India: Current Science India, v. 90 , p. $58-64$.

Baskar, S., Baskar, R., Lee, N., and Theophilus, P.K., 2009, Speleothems from Mawsmai and KremPhyllut caves, Meghalaya, India: some evidences on biogenic activities: Environmental Geology, v. 57, p. 1169-1186. doi:10. 1007/s00254-008-1413-y.

Bäuerlein, E., ed., 2004, Biomineralization: Progress in Biology, Molecular Biology and Application, second edition: Weinheim, Wiley-VHC Verlag, $361 \mathrm{p}$.

Boquet, E., Boronat, A., and Ramos-Cormenza, A., 1973, Production of calcite (calcium carbonate) crystals by soil bacteria is a general phenomenon: Nature, v. 246, p. 527-529. doi:10.1038/246527a0.

Cao, Xianhua, Liu, Xiaoli, and Dong, Xiuzhu, 2003, Alkaliphiluscrotonatoxidans sp. nov., a strictly anaerobic, crotonate-dismutating bacterium isolated from a methanogenic environment: International Journal of 
Systemic and Evolutionary Microbiology, v. 53, p. 971-975. doi:10.1099/ ijs.0.02373-0.

Cuezva, S., Sanchez-Moral, S., Saiz-Jimenez, C., and Cañaveras, J.C., 2009, Microbial communities and associated mineral fabrics in Altamira Cave, Spain: International Journal of Speleology, v. 38, p. 83-92. doi:10.5038/ 1827-806X.38.1.9.

Daly, B.D.K., 2009, Meghalaya's underground treasures, in Glimpses from the North-East: National Knowledge Commission, p. 49-54.

Daskalakis, M.I., Rigas, F., Bakolas, A., Magoulas, A., Kotoulas, G., Katsikis, I., Karageorgis, A.P., and Mavridou, A., 2015, Vaterite bio-precipitation induced by Bacillus pumilus isolated from a solutional cave in Paiania, Athens, Greece: International Biodeterioration\& Biodegradation, v. 99, p.73-84. doi:10.1016/j.ibiod.2014.12.005.

Engel, A.S., Porter, M.L., Kinkle, B.K., and Kane, T.C., 2001, Ecological assessment and geological significance of microbial communities from Cesspool cave, Virginia: Geomicrobiology Journal, v. 18, p. 259-274. doi: $10.1080 / 01490450152467787$.

Engel, A.S., Lee, N., Porter, M.L., Stern, L.A., Bennett, P.C., and Wagner, M., 2003, Filamentous 'Epsilonproteobacteria' dominate microbial mats from sulfidic cave springs: Applied and Environmental Microbiology, v. 69, p. 5503-5511. doi:10.1128/AEM.69.9.5503-5511.2003.

Felsenstein, J., 1985, Confidence limits on phylogenies: an approach using the bootstrap: Evolution, v. 39, p. 783-791. doi:10.2307/2408678.

Holmes, A.J., Tujula, N.A., Holley, M., Contos, A., James, J.M., Rogers, P., and Gillings, M.R., 2001, Phylogenetic structure of unusual aquatic microbial formations in Nullarbor caves, Australia: Environmental Microbiology, v. 3, p. 256-264. doi:10.1046/j.1462-2920.2001.00187.x.

Holt, J.G., Krieg, N.R., Sneath, P.H.A., Staley, J.T., and Williams, S.T., 2000, Bergey's Manual of Determinative Bacteriology: Philadelphia, Lippincott Williams \& Wilkins, 787 p.

Jones, A.A., and Bennett, P.C., 2014, Mineral microniches control the diversity of subsurface microbial populations: Geomicrobiology Journal, v. 31, p. 246-261. doi:10.1080/01490451.2013.809174.

Kim Ok-Sun, Cho Yong-Joon, LeeKihyun, YoonSeok-Hwan, KimMincheol, NaHyunsoo, Park Sang-Cheol, Jeon Yoon Seong, Lee Jae-Hak, Yi Hana, WonSungho, and ChunJongsik, 2012, Introducing EzTaxon-e: a prokaryotic 16S rRNA gene sequence database with phylotypes that represent uncultured species: International Journal of Systemic and Evolutionary Microbiology, v. 62, p. 716-721. doi:10.1099/ijs.0.038075-0.

Legatzki, A., Ortiz, M., Neilson, J.W., Casavant, R.R., Palmer, M.W., Rasmussen, C., Pryor, B.M., Pierson III, L.S., and Maier, R.M., 2012, Factors influencing observed variations in the structure of bacterial communities on calcite formations in Kartchner Caverns, AZ, USA: Geomicrobiology Journal, v. 29, p. 422-434. doi:10.1080/01490451.2011. 581326.

LiXiuli, HuChaoyong, HuangJunhua, XieShucheng, and Baker, A., 2014,A 9000-year carbon isotopic record of acid-soluble organic matter in a stalagmite from Heshang Cave, central China: Paleoclimate implications: Chemical Geology, v. 388, p.71-77. doi:10.1016/j.chemgeo.2014.08.029.

Northup, D.E., and Lavoie, K.H., 2001, Geomicrobiology of caves: a review: Geomicrobiology Journal, p. 18, p. 199-220. doi:10.1080/ 01490450152467750 .

Madigan, M.T., Martinko, J.M., and Parker, J.M., 2003, Brock Biology of Microorganisms, tenth edition: Upper Saddle River, N.J., Prentice Hall. $1019 \mathrm{p}$.

Merz, M.U.E., 1992, The biology of carbonate precipitation by cyanobacteria: Facies, v. 26, p. 81-101. doi:10.1007/BF02539795.

Portillo, M.C., Porca, E., Cuezva, S., Cañaveras, J.C., Sanchez-Moral, S., and Gonzalez, J.M., 2009, Is the availability of different nutrients a critical factor for the impact of bacteria on subterraneous carbon budgets?: Naturwissenschaften, v. 96, p. 1035-1042. doi:10.1007/ s00114-009-0562-5.

Riding, R., 2000, Microbial carbonates: the geological record of calcified bacterial-algal mats and biofilms: Sedimentology, v. 47, no. s1, p. 179214. doi:10.1046/j.1365-3091.2000.00003.x.

Tamura, K., Dudley, J., Nei, M., and Kumar, S., 2007, MEGA4: Molecular Evolutionary Genetics Analysis (MEGA) software version 4.0: Molecular Biology and Evolution, v. 24, p. 1596-1599. doi:10.1093/molbev/ msm092.

Weiner, S., and Dove, P.M., 2003, An overview of biomineralization and the problem of the vital effect, in Dove, P.M., Weiner, S., De Yoreo, J.J., eds., Biomineralization: Washington, D.C., Mineralogical Society of America, Reviews in Mineralogy and Geochemistry 54, p. 1-31. 